\title{
Inclusive Education and Social Justice for All Indonesians
}

\author{
Novia Wahyu Wardhani ${ }^{1, *}$ Muhammad Fauzi Fitri Andika ${ }^{2}$ \\ ${ }^{1}$ Faculty of Social Science, Universitas Negeri Semarang, Semarang 50229, Indonesia \\ ${ }^{2}$ Faculty of Social Science, Universitas Negeri Semarang, Semarang 50229, Indonesia \\ ${ }^{*}$ Corresponding author. Email: noviawahyu@mail.unnes.ac.id
}

\begin{abstract}
Indonesia has 4 objectives stipulated in the 1945 Constitution of the Republic of Indonesia, one of which is to educate the nation's life. The Pancasila ideology also mandates social justice for all Indonesians. These two points are manifested in many programs. One of them is through inclusive education. However, the existence of inclusive education is not in line with the completeness of infrastructure and the mind set of environmental acceptance for those who are different. This raises complex problems for the continuity of children's education, both regular and inclusive. This research is qualitative research with a locus of inclusive education in Central Java, especially in elementary schools. Data obtained from observation, interviews, and documentation. The data validity used source, technique, and data triangulation. Data analysis techniques ranging from data collection to concluding. The result is that Efforts to realize social justice for all Indonesian people through inclusive education cannot arise because of several things that can be achieved from culture, politics, and human resources. Therefore, it is necessary to use social capital that exists in society, such as beliefs, values , and norms, and networks that exist between government, schools, and the community.
\end{abstract}

Keywords: inclusive, education, social justice, Indonesia

\section{INTRODUCTION}

The Government of the Republic of Indonesia since 2000 has made a policy on inclusive education. This policy is a follow-up policy that has developed in various parts of the world. However, during the 20 years running, there are still many obstacles faced in its implementation. From the observations made during 2018-2019 in public and private schools with the logo of an inclusive school, there was always an inadequacy in the management of examples of teachers letting children with special needs shunned by their friends while playing, separating their seats from other friends, absence a psychologist provided by the school, and the absence of a companion teacher for classes with children with special needs.

Implementing inclusive education is not easy. It takes a high commitment from all components of education and society. The 1945 Constitution of the Republic of Indonesia indeed mandates four goals for the state, one of which is to educate the nation's life which comes from the policy of inclusive education. This also follows the Pancasila ideology, in which the government must strive for the creation of social justice for all Indonesian people. The emergence of inclusive education, apart from being an effort to carry out the mandate of the nation's constitution and ideology, is also caused by the increasing world demand for education for all and demands for children's rights. The issuance of this education policy is the government's way of realizing educational goals. [1]

Children with special needs (ABK) in Indonesia according to data from the Central Bureau of Statistics in 2019 there were $70 \%$ of children with special needs, which in 2017 reached 1.6 million people who did not get the proper education. Not only that, based on several studies such as inclusive education in regular schools, it has not been going well (Fernandes, 2018 [1]; Widyawati, 2017[2]; Tarnoto, 2016)[3]. Whereas the educational environment has social capital which should be able to maintain the continuity of inclusive education 
both in quantity and quality. However, it turns out that inclusive education that has been running for 17 years nationally is still unable to meet the educational needs of people with special needs.

The difference between this study and previous research is that the factors to be studied involve three things, namely culture, politics, and human resources. From these three things, a solution is sought through a study of social capital owned by the community and schools, especially the Javanese community where the SD Ummul Quro 'school and SD Sekaran 1 are located so that a solution to the problem is found.

\section{METHOD}

This research is a qualitative research that tries to examine inclusive education in Indonesia as an effort to realize social justice for all Indonesian people, especially in the field of education. The research focus is in Semarang, Central Java in 2020. The aspects studied are cultural, political, and human resources factors (Kwon, 2005). The implementation of inclusive education will also be seen from the index for inclusion (Ainscow, 2013).

Table 1. Index for inclusion asking in-depth questions about the data presented by the informants to obtain clarity. This is done to avoid misinterpretation of the data presented by the informants. Data analysis was carried out from the beginning of the researcher to the end. Starting from data to data presentation and data retrieval. Data were collected through three techniques of observation, interviews, and documentation. From the data collected, it is reduced. To code the data, the researchers used the Atlas. ti software. This software is also used for data validity to conclude.

\section{RESULTS AND DISCUSSION}

The history of the development of inclusive education in Indonesia begins with the policies of the Scandinavian countries (Denmark, Norway, Sweden). They are countries that are concerned with developing education, especially education for all. In the 1960s began studying in Scandinavia to study the mainstreaming and least restrictive environment. Furthermore, in England in 1991 the concept of inclusive education was introduced. The demand for inclusive education in the world has become increasingly real, especially since the world convention on children's rights was held in 1989, and the world conference on education in 1991 in Bangkok resulted in

\begin{tabular}{|l|l|l|}
\hline Creating Inclusive Cultures & Producing Inclusive Policies & Evolving Inclusive Practices \\
\hline 1. $\quad$ building community & 1. developing a setting for all & 1. orchestrating play and learning \\
\hline 2. $\quad$ establishing inclusive values & 2. organizing support for diversity & 2. mobilizing resources \\
\hline
\end{tabular}

Data collection was carried out by observation, interviews, and documentation. Observations were made in regular public and private schools that accept children with special needs such as SD Ummul Quro 'Semarang and SD Negeri Sekaran 1 Semarang. Interviews were conducted with the principal, teachers, parents of regular students, and parents of special needs students. Documentation is obtained from school documents and other documents such as statutory regulations, city and provincial policies, mass media, journals, and books.

The technique of checking the validity of the data used triangulation. Triangulation includes three forms, namely triangulation of sources, triangulation of methods, and triangulation of data. Triangulation of sources is a way of checking whether the data is valid or not by cross-checking the data between one source and another. The data sources here are the resource persons who consist of several components of society such as heads of offices, religious leaders, community leaders, humanists, and the community. Method triangulation is done by comparing data from observations, interviews, and documentation to prove that what happened is an accountable fact. The third triangulation is data triangulation. This triangulation was carried out by the declaration of education for all. The implications of this statement are binding on all members of the conference so that all children without exception (including children with special needs) receive adequate educational services. As a follow-up to the Bangkok Declaration, in 1994 an education convention was held in Salamanca Spain which sparked the need for inclusive education, hereinafter known as "the Salamanca statement on inclusive education". Some of these world declarations then made Indonesia participate in 2004 holding a national convention by producing the Bandung Declaration with Indonesia's commitment towards inclusive education.

The implementation of inclusive education, although it has been going on for a long time, for almost 20 years, it still faces many obstacles. This constraint is based on the results of observations, interviews, and documentation in terms of culture, politics, and human resources, the following results are obtained:

\subsection{Culture}

From the observations at SD Ummul Quro 'school and SD Sekaran 1 Semarang found several problems related to culture: 
a. The fading of the culture of tolerance among students in schools

b. Ongoing discrimination from parents about children with special needs

c. a school culture that does not support good interaction between regular students and $\mathrm{ABK}$

The same thing was found in interviews that parents fear their children side by side with children with special needs, especially children with emotional and mental disorders. They pass on that fear to their children so that the child then makes relationship restrictions which eventually fall into discrimination and even bullying. Minority children in school tend to be discriminated against because many do not accept it (Soemantri, 2020). The results of several studies also state that the acceptance of parents and society for children's conditions will affect their attitudes towards children and this is a challenge and obstacle for inclusive schools where parents and society do not accept child disabilities (Widyawati, 2017; Tarnoto, 2016; Pratiwi, 2015).

In Java, especially Central Java, the Tepa Slira culture must be the initial capital for the acceptance of $\mathrm{ABK}$ in the community and schools. However, it turns out that this is not directly proportional to the form of community acceptance, especially parents of children with special needs at school. This culture of mutual respect must be preserved again, especially in inclusive schools. Because good communication between regular and ABK occurs because of good reception. Culture considers ABK as something that must be avoided, not without cause. Some parents do tell their children to stay away from ABK because they are considered dangerous or dangerous for their children, especially children with emotional and mental disorders. This is done because of hereditary experience and knowledge. This is what makes a culture of rejection by parents and regular children in inclusive schools towards children with special needs. They demanded that $\mathrm{ABK}$ study in special schools that are specifically for $\mathrm{ABK}$ and not be included with the general ones. Even though through educating children with special needs with normal children, they can show significant development (Sadioglu, Batu, Bilgin, and Oksal, 2013) which should be supported by the environment. This community mindset that must be changed, of course, is by building values and beliefs carried out by schools to their environment through school culture and complete school infrastructure as support. For example, some psychologists continue to be at school to monitor and there are shadow teachers who accompany those who work directly with children with special needs during preschool and elementary school (Nasir, Winarni, and Lestari, 2019).

\subsection{Political}

From observations at SD Ummul Quro' school and SD Sekaran 1 Semarang, he found several problems related to politics. Politics is defined as a strategy to achieve goals. Many schools in carrying out their obligations only implement them without being based on the strengthening of adequate infrastructure. Faceseeking politics makes policies only superficially applied. They are accepted as students and ignored by their different needs from other students. What happened in SD Ummul Quro 'and SD Sekaran 1 Semarang was not in neglect, but in the lack of support for facilities and infrastructure by the school so that it seemed as if the school allowed discrimination and was not responsible. From the results of the interview, it was found that the parents of other students were not informed about the existence of ABK in their child's school. When schools were asked, all had gone through the admission procedure, but the supporting facilities and infrastructure were incomplete. From the results of the documentation, the $\mathrm{ABK}$ received there has been screened by psychologists, especially those with emotional and mental disorders, and the school has provided one companion teacher for each class from grades 1-6. However, the accompanying teacher is not someone who understands $\mathrm{ABK}$ even though it is the accompanying teacher who accompanies them in their activities at school.

Inclusive education is indeed an important part of changing the world of education in Indonesia. The implementation of inclusive education is driven by Indonesia's agreement in the Education for All (EFA) international convention and the agreement in the declaration of The Dakar Framework for Action. The agreement in PUS contains education that can be enjoyed by normal people and people with special needs. The fulfillment of children's rights in education becomes clear with the 1945 Constitution of the Republic of Indonesia which regulates education as a right. This provision was later derived from Law No. 20 of 2003 concerning the National Education System and Law Number 8 of 2016 concerning Persons with Disabilities. Implementation in schools is further clarified by the existence of the Regulation of the Minister of National Education of the Republic of Indonesia Number 70 of 2009 concerning Inclusive Education. The existence of these policies has not been able to create an adequate inclusive education environment. Finally, Government Regulation Number 13 of 2020 concerning Adequate Accommodation for Students with Disabilities emerged.

To overcome policies that are only implemented on the surface, a policy analyst is needed to be able to measure whether the school deserves to be an inclusive school or not. Not only that but also policy evaluators are needed to attend schools to evaluate the operation of inclusive schools. Thus, public trust, especially parents, both regular students, and special needs students, is formed to be strong support. 


\subsection{Human Resources}

Inclusive education has several main objectives, namely: 1) to provide opportunities for all children to get a decent education and to accelerate the compulsory basic education program; 2) creating independent, adaptive and quality ABK students (Garnida, 2015); and 3) improving the quality of education (Mayya, Saud, and Meriawan, 2019). So that human resources are needed as support.

Based on the results of observations, interviews, and documentation, human resources are one of the obstacles for schools, especially public and private schools that accept inclusive children. As in SD Ummul Quro 'and SD Sekaran 1 Semarang. Both of them only accept but do not prepare suitable human resources to meet their learning needs. Therefore, the results are also not good, such as the absence of a psychologist and accompanying teachers, especially for children with emotional and mental disorders. Children with both disorders sometimes cannot communicate with friends in general or with ordinary teachers, so there must be special treatment for them and competent human resources to guide them during learning and in class.

The same problem also occurs in several regions. From several studies, it was found that the barriers to inclusive education were mostly caused by the following obstacles:

A. misconceptions of school staff about inclusion;

b. schools have not translated the policy into more technical regulations;

c. inflexible learning process and rigid curriculum;

$\mathrm{d}$. there is still a lack of quantity and quality of special guidance teachers (GPK); and

e. the support system from parents, community, and the government is still weak (Handayani \& Rahadian, 2013; Sulistyadi, 2014; Junaedi, 2016; Tarnoto, 2016; Sheehy, 2017).

Thus, there still needs to be a lot of improvements that must be done by the government and schools to be able to realize appropriate inclusive education for children for the realization of national goals and carry out the mandate of Pancasila to strive for social justice for all Indonesian people.

Social capital that can be used is building a network between the government, schools, teacher providers for special needs students, and psychologists. This network should be established and strengthened to provide the infrastructure for the crew members. The second network is a network of parents of students that must be established with open information and communication on children's development in schools. Current technological advances also support the availability of information needed to build a community mindset for the acceptance of children with special needs in their environment. In national education standards, management and financing can be supported by a network in the community and system support (Melyanti, 2017).

\section{CONCLUSION}

Efforts to realize social justice for all Indonesian people through inclusive education cannot be easily achieved due to several obstacles that arise from culture, politics, and human resources. Therefore it is necessary to use social capital that exists in society, such as beliefs, values, and norms, and networks that exist between government, schools, and the community. Without the supporting factors, namely improving school infrastructure, peer environment, school culture, and the mindset of students' parents, the goals of inclusive education are difficult to achieve. Therefore it is necessary to harmonize and fulfill these factors to support the success of inclusive education.

\section{AUTHORS' CONTRIBUTIONS}

The author here contributes to three things, namely the owner of the idea, the key instrument, the evaluator, and the presenter. For data collection, the author uses special personnel to go down the field to collect the necessary data following the author's direction.

\section{ACKNOWLEDGMENTS}

I would like to thank the author of SD Ummul Quro' and SD Sekaran 1 Semarang, as well as the informants who are willing to provide research data.

\section{REFERENCES}

[1] Oyedeji, S. (2015). Lapses in Education Policy Formulation Process in Nigeria: Implications for the Standard of Education. Journal of Education and Practice, 6(29), 195-202

[2] Fernandes, R. (2018). Adaptasi Sekolah Terhadap Kebijakan Pendidikan Inklusif. SOCIUS, 4(2), 119 125.

[3] Widyawati, R. (2017). Evaluasi Pelaksanaan Program Inklusi Sekolah Dasar. Kelola: Jurnal Manajemen Pendidikan, 4(1), 109-120.

[4] Tarnoto, N. (2016). Permasalahan-permasalahan yang dihadapi sekolah penyelenggara pendidikan inklusi pada tingkat sd. Humanitas: Jurnal Psikologi Indonesia, 13(1), 50-61.

[5] Ainscow, M., et al. (2013). From Exclusion to Inclusion: Ways of Responding in Schools to Students with Special Educational Needs. University of Manchester: Education Trust. 
[6] Sumantri, B. A. (2020). Pendidikan Inklusif dalam Surat al-Hujurat Ayat 10-13 dan Surat Abasa Ayat 1-10. In The Indonesian Conference on Disability Studies and Inclusive Education (Vol. 1, pp. 125140).

[7] Widyawati, R. (2017). Evaluasi Pelaksanaan Program Inklusi Sekolah Dasar. Kelola: Jurnal Manajemen Pendidikan, 4(1), 109-120.

[8] Tarnoto, N. (2016). Permasalahan-permasalahan yang dihadapi sekolah penyelenggara pendidikan inklusi pada tingkat sd. Humanitas: Jurnal Psikologi Indonesia, 13(1), 50-61.

[9] Pratiwi, J. C. (2015). Sekolah inklusi untuk anak berkebutuhan khusus: tanggapan terhadap tantangan kedepannya. In Seminar Nasional Ilmu Pendidikan UNS 2015. Sebelas Maret University.

[10] Sadioglu, O. Batu, S. Bilgin, A dan Oksal, A. 2013. Problem, Expectations, and Suggestion of Elementary Teacher Regarding Inclusion. Educational Science: Theory \& Practice. DOI: 10.12738/estp.20133.1546

[11] Nasir, A., Winarni, I., \& Lestari, R. (2019). The Experience Of Shadow Teachers In Helping Children With Special Needs In Telogo Patut Elementary School I Gresik. Jurnal Ilmu Keperawatan: Journal of Nursing Science, 6(1), 1-9.

[12] Undang-Undang No.12 tahun 2003 tentang Sistem Pendidikan Nasional.

[13] Undang-Undang No. 8 tahun 2016 tentang Penyandang Disabilitas.

[14] Permendiknas No. 70 tahun 2009 tentang Pendidikan Inklusi.

[15] Peraturan Pemerintah Nomor 13 tahun 2020 tentang Akomodasi Yang Layak Untuk Peserta Didik Penyandang Disabilitas.

[16] Garnida, D. (2015). Pengantar Pendidikan Inklusif. Bandung: PT Refika Aditama

[17] Mayya, M., Sa’ud, U. S., \& Meirawan, D. Analisis Implementasi Kebijakan Pendidikan Inklusi Pada Sekolah Dasar. Jurnal Administrasi Pendidikan, 26(1), 108-117.

[18] Handayani, T \& Rahadian, A. (2013). Peraturan Perundangan dan Implementasi Pendidikan Inklusif. Masyarakat Indonesia, 39(1), 27-48.

[19] Sulistyadi, H. (2014). Implementasi Kebijakan Penyelenggaraan Layanan Pendidikan Inklusif di Kabupaten Sidoarjo. Kebijakan dan Manajemen Publik, 2(1), 1-10.

[20] Junaedi, E. (2015). Efektifitas Manajemen Implementasi Kebijakan Inklusif Pada Tingkat
Sekolah Dasar. (Tesis). Sekolah Pascasarjana, Universitas Pendidikan Indonesia, Bandung.

[21] Tarnoto, N. (2016). Permasalahan-permasalahan yang dihadapi sekolah penyelenggara pendidikan inklusi pada tingkat sd. Humanitas: Jurnal Psikologi Indonesia, 13(1), 50-61.

[22] Sheehy, K., et al. (2017). Indonesian Teachers' Epistemological Beliefs and Inclusive education. Journal of Intellectual Disabilities, 20(10), 1-18.

[23] Melyanti, I. M. (2017). Dampak Pengembangan Kapasitas Organisasi Pada Peningkatan Kualitas Pelayanan Pendidikan Inklusif Bagi Anak Berkebutuhan Khusus (ABK) Di SDN Mriyunan Sidayu Gresik (Doctoral dissertation, Universitas Airlangga). 